\title{
Developing Mathematical Communication Problem Solving Ability Using Hot Potatoes Software
}

\author{
Bansu I. Ansari ${ }^{1}$, Fatimah Nur ${ }^{2}$ and Mursalin ${ }^{3}$ \\ \{bansuansari58@gmail.com\} \\ ${ }^{1}$ Department of Mathematics Education, Universitas Serambi Mekkah, Aceh, Indonesia \\ ${ }^{2}$ Department of Mathematics Education, Universitas Syiah Kuala, Aceh, Indonesia \\ ${ }^{3}$ Department of Mathematics Education, Universitas Malikussaleh, Aceh, Indonesia
}

\begin{abstract}
The purpose of this study is to examine the increase of students' mathematical communication ability gained from the learning using problem solving approach with hot potatoes software. Random sampling method was used to collect sample from one of the junior high school in Banda Aceh. The sample consisted of 32 students for experiment class and 32 students for control class. Quantitative method employing t-test and correlation test was employed to analyze the data. The results show that there has been a significant increase of students' mathematical communication ability using the problem solving approach with hot potatoes software; students' mathematical ability of the experiment class is higher than the control class. Furthermore, students in the experiment class have higher self-efficacy and therefore they can formulate a more directed mathematical model for solving geometry problems.
\end{abstract}

Keywords: Problem Solving Approach, Hot Potatoes Software, Mathematics Communication Ability

\section{Introduction}

Mathematics communication is a visualization of both students' verbal and non-verbal abilities for solving problems. NCTM [1] mentioned that mathematics communication is students' ability to present a unique way to solve problems; students' ability to construct and explain real world phenomenon presentation in graph, words or sentences, equation, table and physical presentation; or students' ability to provide conjectures of geometric figures. Greenes and Schulman [2] identified mathematics communication as (1) the ability to express mathematical ideas in oral, written and demonstration forms and to draw it visually into different forms, (2) the ability to understand, interpret and assess ideas presented in written, oral or visual forms. Sullivan and Mousley [3] emphasized that mathematics communication is not just about presenting ideas in a written form; in a broader context, it is students' ability in speaking, explaining, illustrating, listening, questioning, clarifying, working together (sharing), writing and finally reporting what have been learned.

Mastering mathematics communication ability is essential.Thus, this ability should be promoted in each level of education. However, students are often found to have difficulties in communicating mathematics ideas in a written form, especially for the problems of threedimensional (3D) geometry related to daily life. While the ability to translate language into 
mathematical models such as pictures, graphs, pattern and the other modelling form is crucial to solve the problems, students are not able to illustrate the situation of a problem to a mathematics model. In 3D geometry, the ability to illustrate pictures is one of the steps used to assist the process of solving further problem, especially in determining the surface area and volume of 3D geometry objects such as prism and pyramid when presented in word problems. Problem solving approach using hot potatoes software is applied to address this issue. In this model, students are obliged to be able to solve the problem using Polya's version of problem solving and to recheck the results using the software. Problem solving using hot potatoes software positively influence students' motivation and performance (Hung, Huang and Hwang, 2014). The combination of problem solving and hot potatoes software is the solution we proposed to overcome students' difficulties in understanding the topic of 3D geometry. Furthermore, the combination of problem solving and hot potatoes software can also improve students' self-efficacy [3].

The use of the software is recommended by thegovernment to improve learning efficiency and effectiveness (the ministry of education regulation/Permediknas No 22, Year of 2016). Hot potatoes software is one of the software based technology product that can be utilized to create web based quiz interactively and attractively [4]. Hot potatoes software can be used as an evaluation program. The benefits of computer based evaluation program outweigh the paper based test including providing feedback, presenting the test results directly to the students, and time efficiency in assessing students' works.

Hot potatoes software consists of six programs, namely: (1) JQuiz, (2) JMix (jumbledsentence exercises), (3) JCross (Crossword puzzles), (4) JMatch (Matching or ordering exercises), (5) JCloze (Gap-fill exercises) and (6) The Masher.

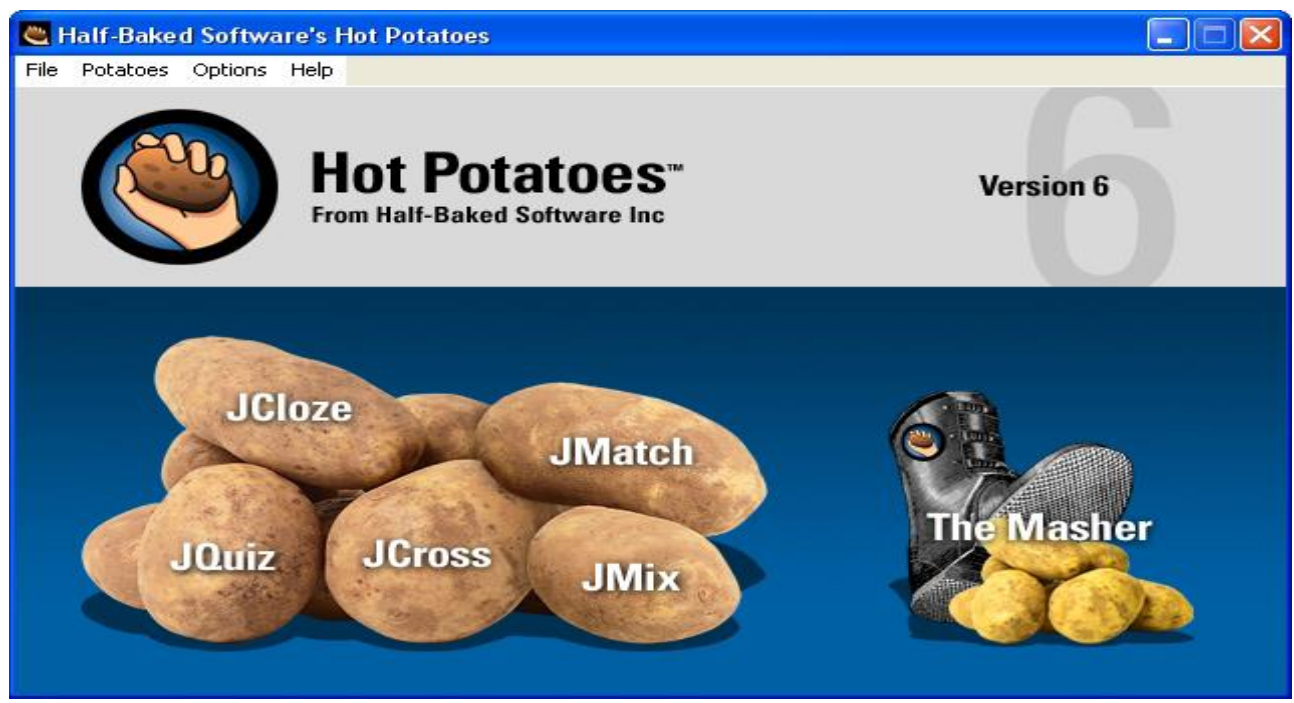

Figure 1. Front display of hot potatoes

The six programs in hot potatoes software can produce some output files that can be formatted in the form of web page (htm), compressed file (Zip), SCORM 1.2 packet file (Zip) or can also be printed or uploaded to the server of LMS supporting standard content of elearning application with SCORM such as LMS and Dokeos. Hung, Huang and Hwang [5] mentioned that JQuizthe program that can be used to prepare four types of exercises including 
multiple-choice, short answer,hybrid (combination of multiple-choice and short-answer) and multi-Select; JMix (jumbled-sentence exercises) is the program that can be used to create exercises of arranging sentences; JCros (crossword puzzles) is the program that can be used to prepare materials in crossword puzzles; JMatch (matching or ordering exercises) is the program that can be used to create exercises in a form of matching exercises; JCloze (gap-fill exercises) is the program that can be used to prepare exercises in a form of fill in the blanks exercise; The Masher is the program that can be used to manage the combination of exercises or problems mentioned before by compiling some types of exercises in hot potatoes. To run the software, the user should choose the preferred types of the program.

\section{Methods}

\subsection{Sampling}

The sample of this study is 64 year 8 students (age 140-15 years old) from one of the junior high school in Banda Aceh. The sample is divided into experiment (32 students) and control group (32 students). Pretest, treatment and post-test are given to the students. The pretest is related to plane geometry related to prism and pyramid.

\subsection{Procedure and Treatment}

The design of the study used "Pretest and Posttest Control Group Design" model. The sample obtained through purposive and random sampling resulting in the experiment and control class. The experiment class learned in group consisting of 5 students, the treatment using Polya's version of problem solving model using hot Potatoes, while control class also learned in group consisting of 5 students, the treatment using Polya's version of problem solving without hot potatoes. The data collection was conducted from April to July 2017.

Both classes learned 3D geometry, the topics of Prism and Pyramid, with the learning technique using students' worksheet. Both classes were guided to implement Polya's steps in problem solving, namely: understanding the problem, planning, conducting the plan, concluding and rechecking the works. In the experiment class, after students have completed the worksheet, they used hot potatoes software. This software presented quiz related to the topic of 3D geometry.

The quiz in this study was conducted as a tournament (game) between groups to encourage students to be actively involved and challenged to answer the problems presented. It is expected that there are no more passive students as this method encourages students to solve the problems smarter, more precisely and accurately. In addition, this method also trains students to be more confident in expressing their opinions to their peers in group. Bandura (1997) stressed that positive encouragement and feeling will result in more positive selfefficacy.

When the five treatments have been completed, post-test of mathematics communication related to $3 \mathrm{D}$ shapes was administered to the students. The test has met the requirements of validity and reliability tests.

1. A prism tub (height is 2 meters) will be fully filled with water. The base of the prism is triangle ( $3 \times 4 \times 5$ meters). How many liters of water are needed to fully fill the tub? 
2. Mr. Amin owns a swimming pool. The swimming pool is a rectangular prism (length is 10 meters and width is 4 meters). The depth of the water at the shallow end is 1 meter and gradually reduced to 2 meters at the deepest end. Illustrate the situation in an easily understood mathematical model! What is the volume of the swimming pool ?.

3. The figure shows a triangular prism name plate. Complete the information of the figures and find the area of the cardboard needed to wrap the name plate!

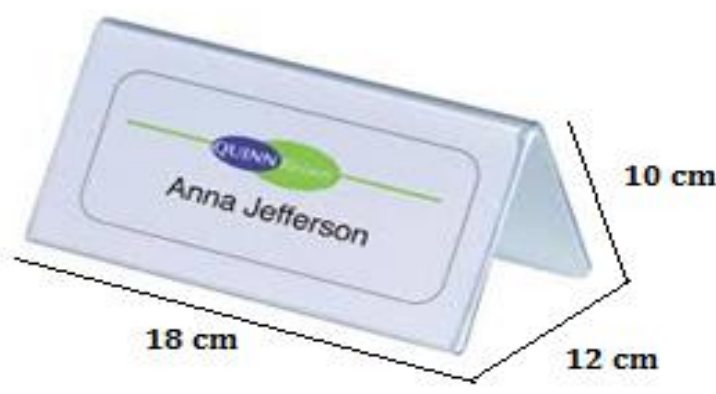

4. A pyramid green house will be renovated. The base of the green house is a rectangle (length is 12 meters and height is 9 meters). The whole surface of the green house will be covered with glass, the glass costs IDR 125.000 per $\mathrm{m}^{2}$. Illustrate the problem and calculate the budget needed to renovate the green house!

\subsection{The Assessment Guidelines of Mathematics Communication Ability}

Table 1. Mathematical communication scoring adapted from Ansari (2016).

\begin{tabular}{|c|c|c|c|}
\hline Score & Qualitative Category & Quantitative Category & $\begin{array}{l}\text { Representa } \\
\text { tion }\end{array}$ \\
\hline \multirow{3}{*}{$80-100$} & \multirow{3}{*}{$\begin{array}{l}\text { Providing complete and } \\
\text { correct answer; being } \\
\text { fluently in providing } \\
\text { various correct answers }\end{array}$} & $\begin{array}{l}\text { The explanation is both mathematical sense making and } \\
\text { correct even though it is lacking in language }\end{array}$ & Written Texts \\
\hline & & $\begin{array}{l}\text { Drawing diagram, pictures or table completely and } \\
\text { correctly }\end{array}$ & Drawing \\
\hline & & $\begin{array}{l}\text { Forming algebraic equation or mathematical model and } \\
\text { then conducting the calculation completely and } \\
\text { correctly }\end{array}$ & $\begin{array}{l}\text { Mathematical } \\
\text { Expressions }\end{array}$ \\
\hline \multirow{3}{*}{$60-79$} & \multirow{3}{*}{$\begin{array}{l}\text { The answer is close to } \\
\text { complete and correct; } \\
\text { being fluently in providing } \\
\text { various correct answers. }\end{array}$} & $\begin{array}{l}\text { The explanation is both mathematical sense making and } \\
\text { correct. However, there are few mistakes. }\end{array}$ & Written Texts \\
\hline & & $\begin{array}{l}\text { Drawing diagram, pictures or table completely and } \\
\text { correctly. However, there are few mistakes. }\end{array}$ & Drawing \\
\hline & & $\begin{array}{l}\text { Using algebraic equation or mathematical model in } \\
\text { conducting the calculation. However, there are few } \\
\text { mistakes. }\end{array}$ & $\begin{array}{l}\text { Mathematical } \\
\text { Expression }\end{array}$ \\
\hline \multirow{3}{*}{$40-59$} & \multirow{3}{*}{$\begin{array}{l}\text { Some of the answers are } \\
\text { complete and correct. }\end{array}$} & $\begin{array}{l}\text { The explanation is mathematical sense making but there } \\
\text { are only some of them are complete and correct. }\end{array}$ & Written Texts \\
\hline & & $\begin{array}{l}\text { Drawing diagram, pictures or table. However, they are } \\
\text { neither complete nor correct. }\end{array}$ & Drawing \\
\hline & & $\begin{array}{l}\text { Using algebraic equation or mathematical model and } \\
\text { conducting the calculation. However, only some of } \\
\text { them are correct and complete. }\end{array}$ & $\begin{array}{l}\text { Mathematical } \\
\text { Expression }\end{array}$ \\
\hline 20- 39 & $\begin{array}{l}\text { The answer is unclear } \\
\text { and procedural }\end{array}$ & $\begin{array}{l}\text { Showing limited understanding of both content of } \\
\text { writing, diagram, figure or table as well as the use of } \\
\text { mathematical model and calculation. }\end{array}$ & $\begin{array}{l}\text { Written Texts, } \\
\text { Drawing, and } \\
\text { Mathematical } \\
\text { Expression }\end{array}$ \\
\hline
\end{tabular}




\section{Results}

\subsection{Recapitulation and Explanation of the Pretest and Posttest Test}

Table 2. Descriptive statistics of students' mathematical communication ability pretest and posttest.

\begin{tabular}{|l|c|c|c|c|c|c|c|c|c|}
\hline \multirow{2}{*}{ Class } & \multirow{2}{*}{$\mathrm{N}$} & \multicolumn{4}{c|}{ Pre-test } & \multicolumn{4}{c|}{ Post-test } \\
\cline { 3 - 11 } & & Min & Max & Mean & SD & Min & Max & Mean & SD \\
\hline Experiment & 32 & 43,7 & 75,6 & 65,73 & 7,69 & 68,4 & 88,7 & 79,84 & 6,46 \\
\hline Control & 32 & 46,3 & 73,5 & 64,90 & 6,91 & 59,2 & 84,8 & 74,61 & 8,29 \\
\hline
\end{tabular}

On average, the posttest results show that the students' mathematical communication ability of both classes is improved. It is observed that the experiment class results are higher considering the difference of pretest and posttest results. However, further analysis for the increase of score gained by both experiment and control class using normalized N-Gain is required. The average N-Gain score of students' mathematical communication ability for both classes is presented in Table 4.

Table 3. Descriptive statistics of Students'mathematical communication ability

\begin{tabular}{|c|c|c|c|}
\hline Class & Mean & Standard Deviation & N \\
\hline Experiment & 0,36 & 0,14 & 32 \\
\hline Control & 0,28 & 0,016 & 32 \\
\hline
\end{tabular}

The N-Gain mean different of the two groups was then analyzed, given that the homogeneity and normality test requirements has been met.

Table 4. N-Gain t-test results of students' mathematical communication ability of experiment and control class.

\begin{tabular}{llcccc}
\hline & & \multicolumn{3}{c}{ t-test for Equality of Means } \\
\cline { 3 - 5 } & & $\mathrm{T}$ & $\mathrm{df}$ & Sig.(2-tailed) \\
\hline $\begin{array}{l}\text { N-gain ofmathematical } \\
\text { communication ability }\end{array}$ & $\begin{array}{l}\text { Equal variances } \\
\text { not assumed }\end{array}$ & 2,001 & 63 & 0,050 \\
\hline
\end{tabular}

It can be concluded that there is a significant different of students' mathematical communication between the experiment and control class. The students who experienced problem solving using hot potatoes reached higher gain of mathematical communication ability.

\subsection{Attempts to Integrate Problem Information}

a. For the answer of question 3 related to the area of cardboard needed to cover a triangular prism name plate. 


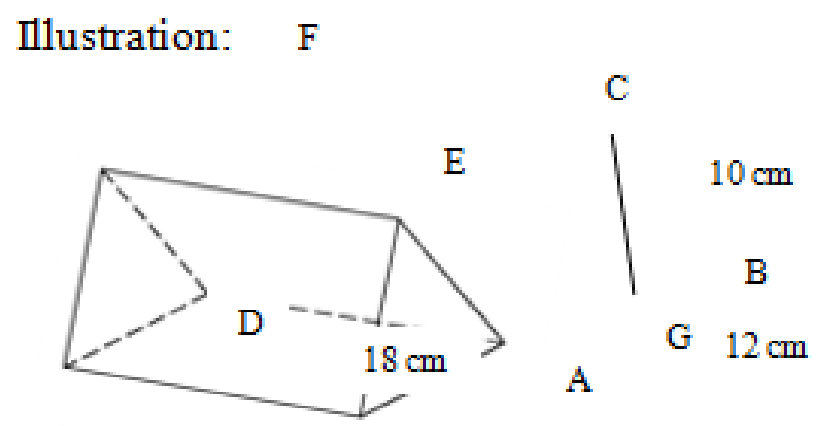

A student from control class started the problem solving by illustrating the correct figure with logical explanation. However, there were some mistakes in the calculation:

$\mathrm{C} G^{2}=\sqrt{C B^{2}-B G^{2}}$

$\mathrm{CG}^{2}=\sqrt{10^{2}-6^{2}}$

$\mathrm{CG}^{2}=\sqrt{100-36}$

$\mathrm{CG}^{2}=\sqrt{64}$

$\mathrm{CG}^{2}=8 \mathrm{~cm}$.

Then he/she calculated the area of the cardboard needed for the seen parts only, including three sides out of five sides of the triangular prism, and the surface area of the prism $=$ The area of base + (all right sides + all left sides $)$

$$
\begin{aligned}
& =\left(\frac{1}{2} \times \mathrm{AB} \times \mathrm{CG}\right)+(\mathrm{AD}+\mathrm{DF}+\mathrm{FC}+\mathrm{CA}) \times 2 \\
= & 48+112 \\
= & 160 \mathrm{~cm}^{2}
\end{aligned}
$$

This is a failed final answer

b. The answer of question 4 of one of the students in experiment class

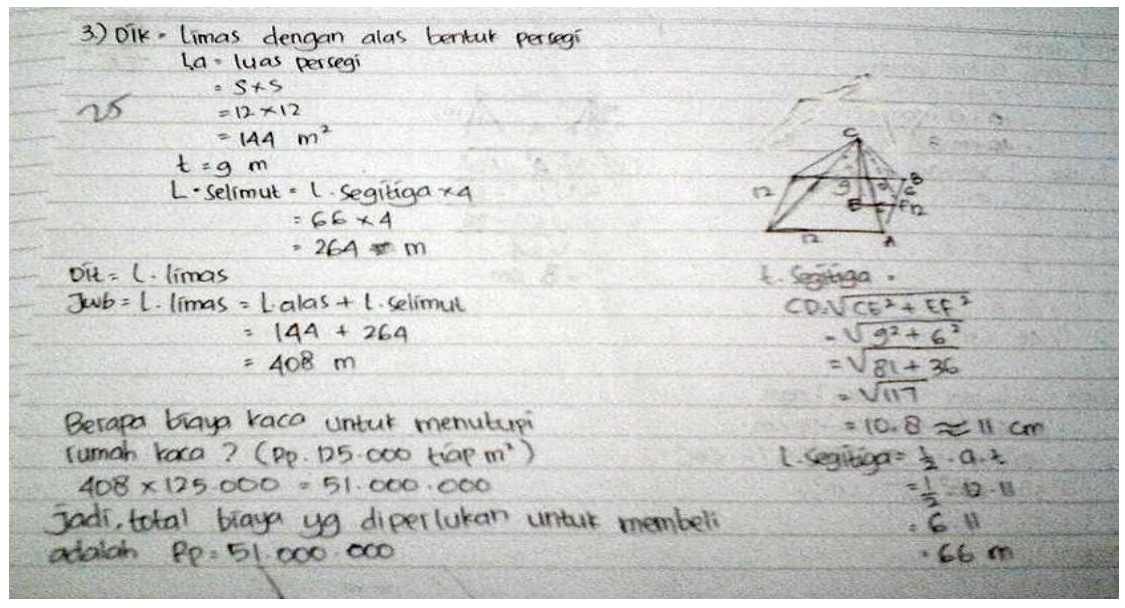

Figure 2. One of student's answer in experiment class 
Based on the answer presented on Figure 2, it is indicated that student's skill in communicating ideas is improving, student could understand and write all information provided in the question. In addition, the answer was systematic, well-planned and corresponding to the figure.

\section{Discussion}

Table 2 indicates that problem solving approach using hot potatoes positively contributes to improve students' mathematical communication ability compare to the problem solving approach without the software. The difference of students' mathematical communication between experiment and control class is due to the different characteristics of both approaches, experiment class using problem solving approach using hot potatoes software with additional innovation; students are trained with the steps of problem solving approach as well as various questions provided by the software in a web display with the working duration decided in advance.

Even though students in control class conducted the Polya's version of problem solving, they were not as enthusiastic in rechecking their answer (looking back) as they were bored (using paper based test) resulting in some failure in the final answer. This is not the case with the students using hot potatoes software, the software enables various feedbacks without paper so that students can directly see their test results without a long wait. This is also indicated by control class students' answer of question no 2 mentioned before, they make an illustration to clarify the problem, however, they still have difficulty in illustrating all the information obtained in the appropriate mathematical models.

The results of this study are relevant to previous research by Esty and Teppo [7] who found that students are able to solve problems given in the forms of narrative drawings but students failed to build a problem solving formula. Therefore, it is expected that school can utilize information technology and communication (both hardware and software) in the teaching and learning to improve students' cognitive ability. This is in line with Hung, Huang and Hwang [8] who argued that the feedbacks using computer and information technology such as e-book, wireless network, and multimedia encourage students to learn mathematics. Chao, Chen, Star, and Dede [3] also mentioned that technology based resources is one of the solution that can be used to develop higher students' confidence in mathematics problem solving.

Ansari [4] identified some factors contributed to poor mathematical communication ability of the students, as experienced by students in control class, including: prior knowledge, reading, discussion and writing ability, as well as mathematical knowledge. NCTM (2000) emphasized that communication is crucial in mathematics education as it allows teacher to better understand students' ability in interpreting and expressing their understanding of the concepts and processes of mathematics they learned. In line with NCTM, Brodie (2010) claimed that"mathematics reasoning assumes mathematical communication. Communication is an integral part of process reasoning".

Bloom [7] argued that there are three parts of understanding, namely, translation, interpretation and extrapolation understanding. Translation understanding is the ability to understand an idea expressed in a different way from the original statement. For example, one can change a question into symbol or vice versa. Interpretation understanding is the ability to understand an idea arranged in another form such as equation, graph, table and diagram. 
Extrapolation understanding is the ability to predict the continuation of the current tendency based on certain data.

Mathematical communication is inseparable from the process of understanding. Therefore, mathematical communication ability can be observed when student explain an algorithm to solve mathematics problems. Ernest [9] proposed that communication emphasized on students' ability and skills in using words, notation, pictures, table and mathematics structure in reasoning, connection and problem solving.

Based on students' answers, there are three cognitive processes conducted by students in selecting and choosing the rules of solving geometry problems. The students use drawing as a model, formulating mathematics equations (associating ideas), describing in their own words (written text), and a combination of all those aspects. In this case, the focal cognitive process is students' ability in mathematical representation [12]. Drawing was frequently used by both classes. Furthermore, formulating mathematical models and explaining based on students' own expression (written text) were also frequently used by the both classes, whereas the combination of drawing, formulating a mathematical model, and constructing their own expressions were more frequently used by the experimental class.

Table 2 indicates that there is a significant different of the increase score of students in experiment and control class using normalized N-Gain. On average, N-gain of students' mathematical communication of experiment class is higher than control class. The results show that the topic of 3D geometry taught using hot potatoes positively contribute students' success in the final test.

\section{Conclusions}

To sum up, the increase of students' mathematical communication ability in the class taught using problem solving approach using hot potatoes software is better than those class taught using problem solving approach without the software. Students who learned using hot potatoes software acquire Polya's problem solving skills so that they are more directed in formulating mathematics model compared to the students' who learn without the software; they also achieve better results. In addition, problem solving approach using hot potatoes software positively influence students' self-efficacy. This study investigates students' mathematical communication ability limited to the topics of prism and pyramid and it is expected that further research can develop the learning utilizing problem software approach using hot potatoes software for different abilities and broader topics.

\section{References}

[1] Nasional Council of Teachers of Mathematics.Professional Standards forTeachingMathematics. Reston, VA

NCTM, (1991) 95-96

[2] Nasional Council of Teachers of Mathematics.Principles and Standards for School Mathematics.Reston, VA: NCTM, (2000) 127-129.

[3] Sullivan, P \& Mousley, J. (1996). Natural Communication in Mathematics Classroom: What Does it Look Like. In P. C. Clarkson. (Ed).Technologyin Mathematics Education. Melbourne: Merga, (1996) 398-403. 
[4] Ansari, B.I. (2016). Komunikasi Matematik, Strategi Berpikir dan Manajemen Belajar [Mathematical communication, Thinking strategy and Learning Management]. Banda Aceh: Yayasan PeNA.

[5] Bandura, A (1997). Self-Efficacy : The Exercise of Control. New York: wh Freemann and Company

[6] Brodie, K. (2010). Teaching Mathematical Reasoning in secondary Schools. New York: Spinger.

[7] Bloom, B. S. (1971).Taxonomy of Objectives: The Classification of Educational Goals. Handbook I. Cognitif Domain. New York: David McKay Company, Inc.

[8] Chao, T., Chen, J., Star, J. R., \&Dede,C. (2016). Using Digital Resources for Motivation and Engagement in Learning Mathematics: Reflections from Teachersand Students. Digit Exp Math Educ, (2),253-277. doi: 10.1007/s40751-016-0024-6.

[9] Ernest, P. (1991). The Philosophy of Mathematics Education.London: Falmer Press.

[10] Esty, W.W. \& Teppo, A.R. "Algebraic Thinking, Language, and Word Problem". In P.C Elliott, and M.J. Kenney (Eds.). 1996 Yearbook.Communication in Mathematics, K-12 and Beyond. USA: NCTM, (1996) 45-52.

[11] Fonna, M., \& Mursalin, M. (2018). Role of Self-Efficacy Toward Students' Achievement in Mathematical Multiple Representation Ability (MMRA). Jurnal Ilmiah Peuradeun, 6(1), 3140.

[12] Greenes, C., \& Schulman, L. (1996).Communication Processes in Mathematical Explorations and Investigations. In P. C. Elliot and M. J Kenney (Eds).1996Yearbook.Communication in Mathematics, K-12 and Beyond. USA:NCTM (1996) 159-169

[13] Hung, C.M., Huang, I., \& Hwang, G. J. (2014). Effects of digital game-based learning on students' self- efficacy, motivation, anxiety, andachievement in learning mathematics. J. Comput. Educ,1(2-3),151-166. doi: 10.1007/s40692-014-0008-8.

[14] MacGregor, M. \& Stacey, K. "Using Algebra to Solve Problem: Selecting, Symbolising, and Integrating Information". In P.C. Clarkson. (Ed.). Technology in Mathematics Education. Melbourne: Merga, (1996) 360-366 